\title{
Effects of litters with different concentrations of phenolics on the competition between Calluna vulgaris and Deschampsia flexuosa
}

\author{
Jantineke D. Hofland-Zijlstra • Frank Berendse
}

Received: 9 October 2008 / Accepted: 13 May 2009 /Published online: 27 May 2009

(C) The Author(s) 2009. This article is published with open access at Springerlink.com

\begin{abstract}
We hypothesized that the outcome of competition between ericaceous plants and grasses is strongly affected by the concentrations of phenolics in the litter that they produce. To test the effect of phenolic-rich litter on soluble soil nitrogen concentrations, plant nitrogen uptake and inter-specific competition, we conducted a greenhouse experiment with the shrub Calluna vulgaris and the grass Deschampsia flexuosa and their leaf litters. Two litters of $C$. vulgaris were used, with equal nitrogen concentration but different (high and low) concentrations of total phenolics. The D. flexuosa leaf litter contained lower concentrations of phenolics, but higher concentrations of nitrogen than the $C$. vulgaris litters. The plants were grown in monocultures and in mixed cultures. Inorganic and dissolved organic nitrogen were measured monthly during the experiment. After four months, we measured above- and belowground biomass and the nutrient concentrations in above- and belowground plant parts. In monocultures, C. vulgaris produced more shoot and root biomass on its own litter than with no litter. Growth of Calluna was reduced on grass litter. D. flexuosa plants produced most biomass on their own litter type,
\end{abstract}

Responsible Editor: Erik A. Hobbie.

J. D. Hofland-Zijlstra $\cdot$ F. Berendse $(\bowtie)$

Nature Conservation and Plant Ecology Group,

Wageningen University,

P.O. Box 47, 6700 AA Wageningen, The Netherlands

e-mail: frank.berendse@wur.nl whether in monocultures or in mixed cultures. Addition of Calluna litter stimulated the growth of $D$. flexuosa both in monoculture and in mixtures. The grass plants outcompeted Calluna both on shrub litter and on grass litter but not when grown without litter. The two C. vulgaris litter types that differed in their concentration of phenolics did not differ in their effects on the competition between the two species or on the production of inorganic and dissolved organic nitrogen. We conclude that the nitrogen content of the litter is more important as a plant feature driving competition between shrubs and grasses than the concentrations of phenolics.

Keywords Calluna vulgaris . Competition . Deschampsia flexuosa . Dissolved organic nitrogen . Phenolics
Abbreviations
dw dry weight
DON dissolved organic nitrogen
ITS internal transcribed spacer

\section{Introduction}

Dutch heathlands used to be dominated by the evergreen dwarf shrubs Calluna vulgaris (L.) Hull and Erica tetralix L., but during the past few decades these species have been increasingly replaced by the 
perennial grasses Deschampsia flexuosa (L.) Trin. and Molinia caerulea (L.) Moench. High levels of nitrogen deposition have strongly accelerated the accumulation of soil organic matter and the successional change from heathlands into grass-dominated vegetation and woodland (Berendse and Aerts 1984; Berendse and Elberse 1990; Berendse 1994). Previous experiments investigating competition between dwarf shrubs and dominant grasses have shown that the dominant grasses benefit more rapidly from an increased nutrient supply than the dwarf shrubs due to their faster growth rate at higher nutrient levels (Berendse and Aerts 1984; Heil and Bruggink 1987). At lower nutrient levels ericaceous plant species are more competitive, as they are better able to conserve the absorbed nutrients (Berendse et al. 1987; Berendse and Elberse 1990).

As a consequence of features that increase leaf life spans and reduce nutrient losses from the plant (Berendse 1994), ericaceous plants can suppress nitrogen mineralisation by producing slowly decomposable litters rich in lignin and phenolics. Tannins from degrading litter can react with protein sources in the soil to form complexes with proteins. It has been suggested (Northup et al. 1995, 1998; Inderjit and Mallik 1999; Kraus et al. 2003) that these nitrogenrich complexes release inorganic nitrogen slowly and increase the production of dissolved organic nitrogen relative to that of $\mathrm{NH}_{4}^{+}$and $\mathrm{NO}_{3}{ }^{-}$. As ericoid mycorrhizal fungi are able to degrade these complexes (Bending and Read 1997), dwarf shrubs colonized by these fungi are able to absorb more organic nitrogen compared to non-colonized plants (Smith and Read 1997; Sokolovski et al. 2001). Grass species, on the other hand, predominantly colonized by arbuscular mycorrhizal fungi, are often assumed to be less able to utilize organic soil nitrogen. Although it has been shown that arbuscular mycorrhizal fungi can enhance amino acid absorption in plants, this seemed to occur only to a small extent (Hodge 2001; Hodge et al. 2001). Separate from this, there is evidence that grasses can absorb simple forms of organic nitrogen such as amino acids like glycine or methylamine (Näsholm et al. 1998; FalkengrenGrerup et al. 2000). It is, however, not yet shown whether grasses are also able to access more complex organic nitrogen sources. So, it is still unclear whether both $C$. vulgaris and D. flexuosa have equal access to the same sources of organic nitrogen when present in more complex forms. An intriguing, but still unresolved issue is whether dwarf shrubs really gain a competitive advantage over dominant grasses by producing recalcitrant litter with high contents of phenolics that suppress grass growth.

To date, the effect of phenolics on the competition between heather and grasses has not been investigated. Previous experiments on competition between heather species and dominant grasses have focused primarily on the direct effect of additional inorganic nitrogen on the outcome of the competition (Berendse and Aerts 1984; Aerts and Berendse 1988; Aerts et al. 1990; Mickel et al. 1991; Alonso et al. 2001; Britton et al. 2003; Barker et al. 2004). Our hypothesis is that due to ericoid mycorrhizal fungi, ericaceous plants compete more efficiently with $D$. flexuosa on nutrient-poor soils amended with litter rich in phenolics than on nutrient-poor soils amended with litter with low phenolics concentrations. D. flexuosa roots are mainly colonized by arbuscular mycorrhizal fungi, so though the species is able to use dissolved organic nitrogen, we speculate it to do so less than $C$. vulgaris.

In the study reported here, we examined competition between $D$. flexuosa and $C$. vulgaris in a greenhouse experiment. We studied the effects of litter amendments with high and low concentrations of phenolics on this interaction. In many cases concentrations of phenolics and nitrogen are inversely correlated, but in an earlier field experiment with shading treatments we were able to produce Calluna litter with different concentrations of phenolics but similar nitrogen concentrations, so that we could avoid this important pitfall.

\section{Materials \& methods}

\section{Litter treatments}

We performed a competition experiment between $D$. flexuosa and C. vulgaris in a greenhouse. As litter treatments we added grass and shrub litters with high and low concentrations of phenolics (Table 1). $C$. vulgaris litter was collected from $C$. vulgaris plants in shaded and non-shaded treatments $(50 \%$ light reduction) in a field experiment in De Hoge Veluwe National Park that ran from September 2001 to March 2003. Leaf material of $D$. flexuosa was collected in 
Table 1 Overview of litter treatments included in this study

\begin{tabular}{ll}
\hline Litter codes & Litter treatments \\
\hline No litter & No litter \\
Cv-h & C. vulgaris (high phenolics) \\
Cv-l & C. vulgaris (low phenolics) \\
Df & D. flexuosa \\
\hline
\end{tabular}

Each treatment consisted of $2 \times 6$ monocultures of $C$. vulgaris or D. flexuosa, 6 mixtures of C. vulgaris and D. flexuosa and 6 pots without plants

the same area. The leaves were dried at $38^{\circ} \mathrm{C}$ for two days and sieved ( $1 \mathrm{~mm}$ mesh size) before grinding.

To measure concentrations of total phenolics and condensed tannins $20 \mathrm{ml}$ of $50 \%(\mathrm{v} / \mathrm{v})$ methanol was added to $0.19 \mathrm{~g}$ dry leaf material. The mixture was covered and placed in a water bath $\left(75^{\circ} \mathrm{C}\right)$ for $1 \mathrm{~h}$. The sample was then filtered through a glass filter and the extract adjusted to $50 \mathrm{ml}$ with $50 \%(v / v)$ methanol. Total phenolics (measuring both concentrations of hydrolysable and condensed tannins) were analysed with the Folin Ciocalteu method as described in Waterman and Mole (1994). The concentration of condensed tannins were analysed following the butanol-HCl method described by Porter et al. (1986). Given the complexities of applying an appropriate standard for the proanthocyanidin method (Waterman and Mole 1994), the data are presented as final absorbance at $550 \mathrm{~nm}$ for the extracted sample of plant material $(0.19 \mathrm{~g})$. Absorbance values are not recalculated to standard units, since the relationship between absorbance and sample size is not linear.

Concentrations of phenolics and condensed tannins were much lower in the brown Calluna litter than in the green shoots collected from the field experiment. In the non-shaded treatment concentrations of total phenolics in the brown litter were $42 \mathrm{mg}$ tae/g compared to $707 \mathrm{mg}$ tae/g in the green shoots; concentrations of condensed tannins in the litter were 0.02 versus $0.04 \mathrm{~A}_{550} / 0.19 \mathrm{~g}$ in the green material. In the shaded treatment similar differences were found. The measured concentrations of condensed tannins in Calluna material were extremely low compared to concentrations $\left(0.15-0.18 \mathrm{~A}_{550} / 0.19 \mathrm{~g}\right)$ measured in an earlier explorative field study (Zijlstra and Berendse 2009).

A subsample of the plant material was dried at $70^{\circ} \mathrm{C}$ and pulverized to measure the carbon and nitrogen concentrations with an elemental analyser (Fisons Instruments, EA 1108). The ericaceous litter collected from the treatments was found to have similar nitrogen concentrations, but significantly different concentrations of total phenolics (Table 2).

Experiment

In the litter treatments, $5 \mathrm{~g}$ litter dry weight with particles smaller than $1 \mathrm{~mm}$ diameter was mixed with $1.7 \mathrm{~kg}$ soil and used to fill plastic pots (diameter $14 \mathrm{~cm}$ ). The amount of litter added was equal to $325 \mathrm{~g} / \mathrm{m}^{2}$ which was comparable with the aboveground litter production in dry heathland that varies between 250 and $400 \mathrm{~g} \mathrm{~m}^{-2} \mathrm{y}^{-1}$. The nutrient-poor soil substrate was prepared by mixing five parts sand without organic matter and one part black top soil. The organic matter content of the soil mixture (before litter addition) was $1.3 \%$, and $\mathrm{pH}\left(\mathrm{H}_{2} \mathrm{O}\right)$ and $\mathrm{pH}(\mathrm{KCl})$ were 6.4 and 6.0, respectively. Total $\mathrm{N}$ and $\mathrm{P}$ contents were 345 and $163 \mathrm{mg} \mathrm{kg}^{-1}$, respectively. Control pots were filled with soil without added litter. C. vulgaris seedlings up to 1-year old were collected from "De Hoge Veluwe National Park", a dry sandy area in the central part of the Netherlands. D. flexuosa seeds supplied by a private company (De Cruydthoek, the Netherlands) were germinated on soil and were 2 weeks old at the start of the experiment in May 2003. We assumed the young Calluna plants to be inoculated with mycorrhizal fungi, since they were transplanted from the field including some of the native soil adhering to their roots. The plants were grown either in monocultures or mixed with the other species at densities of six plants (six C. vulgaris plants, six D. flexuosa seedlings or three of each). At the start of the experiment the plants were sufficiently short (average height $C$. vulgaris, $3.8 \pm 0.5 \mathrm{~cm}, D$. flexuosa $4.6 \pm 0.4 \mathrm{~cm}$ ) and spaced far enough apart to ensure minimum competition for light. To avoid disturbing effects on plant growth (and for reasons explained in the next paragraph), we included control pots without plants in order to be able to measure the amounts of inorganic and dissolved organic soil nitrogen and $\mathrm{pH}-\mathrm{H}_{2} \mathrm{O}$ during the experimental period of 20 weeks. Each treatment was replicated six times. The treatments were set out randomly in a greenhouse with controlled climatic conditions (light/dark: 14/10 h, light intensity $50 \mathrm{~W} \mathrm{~m}^{-2}$, temperature $20^{\circ} \mathrm{C}, 70 \%$ 
Table 2 Overview of concentrations (means \pm standard errors) of total phenolics, condensed tannins, carbon and nitrogen in the litter material of $C$. vulgaris and D. flexuosa used as treatments in the monocultures and mixed cultures

\begin{tabular}{|c|c|c|c|c|}
\hline Litter & Total phenolics (mg tae/g dw) & Condensed tannins $\left(\mathrm{A}_{550} / 0.19 \mathrm{~g} \mathrm{dw}\right)$ & $\mathrm{C}(\mathrm{mg} / \mathrm{g})$ & $\mathrm{N}(\mathrm{mg} / \mathrm{g})$ \\
\hline D. flexuosa & $1.27 \pm 0.04$ & $0.00 \pm 0.00$ & $447 \pm 1.6$ & $24.3 \pm 0.13$ \\
\hline C. vulgaris (high phenolics) & $42.2^{\mathrm{b}} \pm 0.35$ & $0.02^{\mathrm{ns}} \pm 0.009$ & $504^{\mathrm{ns}} \pm 3.1$ & $16.4^{\mathrm{ns}} \pm 0.15$ \\
\hline C. vulgaris (low phenolics) & $27.1^{\mathrm{a}} \pm 0.23$ & $0.00^{\mathrm{ns}} \pm 0.006$ & $517^{\mathrm{ns}} \pm 3.6$ & $18.4^{\mathrm{ns}} \pm 0.32$ \\
\hline
\end{tabular}

Concentrations of total phenolics are indicated as tannic acid equivalents (tae) per gram dry weight and concentrations of condensed tannins as the absorbance measured at $550 \mathrm{~nm}$ wavelength $\left(\mathrm{A}_{550}\right)$. Different letters indicate significant differences between $C$. vulgaris litters with high and low concentrations of total phenolics (Tukey test, $P<0.05$ )

$n s$ non-significant

relative humidity). The pots were weighed and watered three times a week to keep the soil moisture at $60 \%$ of water saturation.

\section{Measurements}

During the experimental period we measured biweekly the amounts of inorganic and dissolved organic soil nitrogen and $\mathrm{pH}-\mathrm{H}_{2} \mathrm{O}$ in soil water suctioned from the pots. The pots were watered a day before the measurement and in the morning a syringe with suction cups was placed in a hole $3 \mathrm{~cm}$ above the bottom of each pot to collect sufficient water $(30 \mathrm{ml})$ for the measurements. $\mathrm{NH}_{4}-\mathrm{N}$ and $\mathrm{NO}_{3}-\mathrm{N}$ in the soil solution were directly determined in the collected soil water. Total dissolved nitrogen (dissolved organic nitrogen $(\mathrm{DON})+$ inorganic $\mathrm{N}$ ) was determined conductimetrically after persulphate oxidation (Yu et al. 1993). DON was calculated by subtracting inorganic nitrogen from the total dissolved nitrogen. These measurements were taken in pots that did not contain any plants in order to estimate the amount of $\mathrm{N}$ available for plant uptake during the period of study.

At the end of the experiment heights of the individual plants (averaged over all treatments) of Calluna and Deschampsia had increased by 155 and $72 \%$ of their initial heights, respectively. Plants were harvested on 29 September 2003 and then dried at $70^{\circ} \mathrm{C}$ to measure dry weight. At harvest we distinguished between living and dead plant parts. Roots were carefully rinsed and cleaned from organic soil particles using tweezers. Carbon and nitrogen concentrations in the plant were measured with an elemental analyser (Fisons Instruments, EA 1108).

\section{Statistical analyses}

The effects of litter and competition on shoot and root biomass and soil nitrogen uptake were analysed by two-way ANOVA. The fixed factors were plant treatment (monoculture or mixture) and litter treatment (no litter, C. vulgaris high phenolics, C. vulgaris low phenolics and D. flexuosa). Block effects were initially included as random factor, but removed from further ANOVA analyses because they were found to be not significant. Multiple comparisons between treatments were made using Tukey's test $(P<0.05)$. We analysed the differences in shoot biomass production between the two species using the ratio between the biomass of the grass and the biomass of C. vulgaris in mixed culture. The same was done for the root biomass and shoot:root ratios. Effects of litter were analysed by one-way ANOVA (Tukey's test, $P<$ $0.05)$. We used a repeated measures analysis for soil inorganic nitrogen, dissolved organic nitrogen, ratio organic nitrogen: inorganic nitrogen and $\mathrm{pH}-\mathrm{H}_{2} \mathrm{O}$. To avoid confounding effects of plant growth, we measured control pots without plants only. Therefore there are no plant treatments in this analysis.

\section{Results}

\section{Plant biomass}

C. vulgaris plants in the monocultures produced significantly more shoot biomass on their own litter than on the grass litter and in the treatment without litter (Fig. 1, Table 3). Addition of D. flexuosa litter strongly reduced the amount of $C$. vulgaris shoot biomass. Moreover, the plants in this treatment 

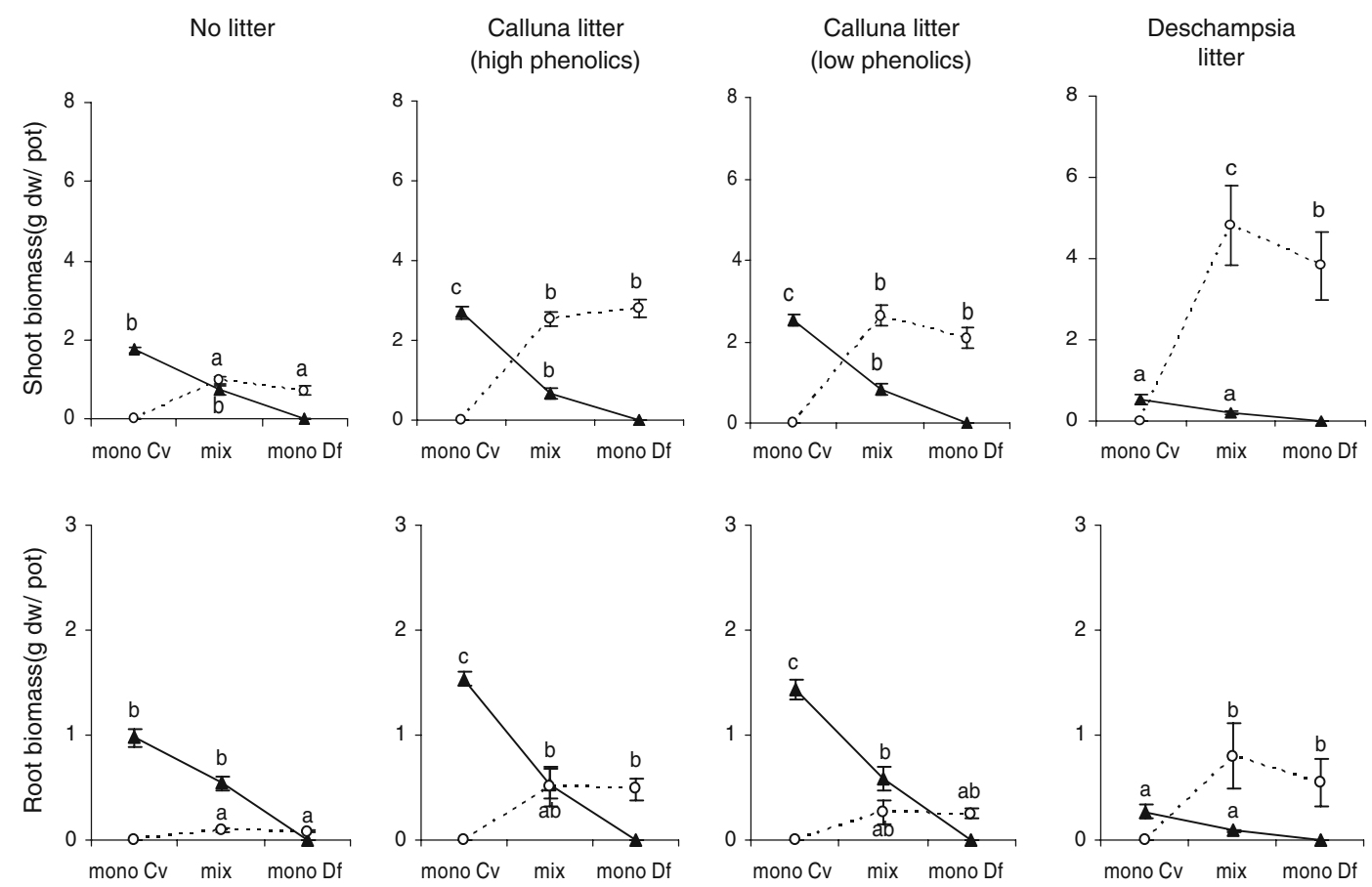

Fig. 1 Replacement diagrams showing the effects of litter treatments on the competition between plants of $C$. vulgaris and D. flexuosa. Mean shoot and root biomass per pot and their standard errors $(n=6)$ are plotted versus the number of plants of the species involved (6 in monocultures and 3 per species in

contained the most dead shoot mass (Table 3, $P<$ 0.05). Also in the mixed cultures, C. vulgaris plants produced much less shoot biomass on D. flexuosa litter than in the other treatments. In the mixtures there was no positive effect of the $C$. vulgaris litter relative to the treatment without litter. We did not find any significant difference in shoot or root biomass between the two $C$. vulgaris litter types. The shoot: root ratio of $C$. vulgaris varied between 1.4 and 2.5 and tended to be highest in the D. flexuosa litter treatments.

Grass plants in mixture produced most shoot biomass on their own litter, but in the monocultures there were no significant differences between the grass and shrub litter treatments due to the large biomass variance in the grass treatment (Fig. 1). In both monocultures and mixtures, shoot biomass of grasses in the treatments with shrub litter was significantly greater than in the pots without litter. There were no differences in grass shoot or root mass between the two shrub litter treatments. In mixtures, the grass benefited greatly from the

mixtures). Different letters indicate significant differences in biomass among litter treatments (Tukey test, $P<0.05$ ). $C$. vulgaris—solid lines, D. flexuosa-broken lines. Calluna monocultures, Deschampsia monocultures, mixed cultures, litter treatments

addition of grass litter, but shrub growth was significantly suppressed (Fig. 3, Table 4). Overall, the shoot: root ratio of $D$. flexuosa was almost triple the shoot: root ratio of the $C$. vulgaris plants and varied between 7.2 and 15.5.

The effects of the treatments on the competitive balance between the two species was further analysed by calculating the ratios between the biomass of the two species in mixture (Table 4). The greatest biomass of $C$. vulgaris relative to $D$. flexuosa was found in the treatment without litter and the lowest nitrogen availability. The difference in shoot biomass between $C$. vulgaris and $D$. flexuosa plants in the mixed culture was much smaller on the two $C$. vulgaris litter types than in the $D$. flexuosa litter treatment. In the grass litter treatment $D$. flexuosa became strongly dominant.

Nitrogen uptake by plants

C. vulgaris plants grown in monocultures showed the highest nitrogen uptake on their own litter, but in the 
Table 3 Effects of litter treatment and competition mode on shoot and root mass, shoot:root ratio, total nitrogen content of the plant and C:N ratio of total plant biomass in C. vulgaris and D. flexuosa plants

\begin{tabular}{|c|c|c|c|}
\hline Plant & $\begin{array}{l}\text { Litter } \\
\mathrm{F}_{3,15}\end{array}$ & $\begin{array}{l}\text { Competition } \\
\mathrm{F}_{1,15}\end{array}$ & $\begin{array}{l}\text { Litter } \times \text { Competition } \\
\mathrm{F}_{3,15}\end{array}$ \\
\hline \multicolumn{4}{|l|}{ C. vulgaris } \\
\hline green shoot mass & $29.696 * * *$ & $21.559 * * *$ & $4.318^{* *}$ \\
\hline dead shoot mass & $17.071 * * *$ & $0.107^{\mathrm{ns}}$ & $0.955^{\mathrm{ns}}$ \\
\hline root mass & $23.049 * * *$ & 2.932 & $1.343^{\mathrm{ns}}$ \\
\hline shoot:root ratio & $2.247^{\mathrm{ns}}$ & $1.112^{\mathrm{ns}}$ & $0.076^{\mathrm{ns}}$ \\
\hline total nitrogen & $20.954 * * *$ & $15.931 * * *$ & $1.955^{\mathrm{ns}}$ \\
\hline $\mathrm{C}: \mathrm{N}$ ratio & $35.463 * * *$ & $36.500 * * *$ & $3.636^{*}$ \\
\hline \multicolumn{4}{|l|}{ D. flexuosa } \\
\hline green shoot mass & $15.777 * * *$ & $31.124 * * *$ & $3.072 *$ \\
\hline dead shoot mass & $4.530^{* *}$ & $0.044^{\mathrm{ns}}$ & $1.233^{\mathrm{ns}}$ \\
\hline root mass & $8.689 * * *$ & $8.825^{* *}$ & $0.804^{\mathrm{ns}}$ \\
\hline shoot:root ratio & $1.744^{\mathrm{ns}}$ & $3.663^{\mathrm{ns}}$ & $0.937^{\mathrm{ns}}$ \\
\hline total nitrogen & $42.347 * * *$ & $48.449 * * *$ & $3.379 *$ \\
\hline $\mathrm{C}: \mathrm{N}$ ratio & $7.787 * * *$ & $17.781^{* *}$ & $0.435^{\mathrm{ns}}$ \\
\hline
\end{tabular}

Effects are analyzed using a two-way ANOVA with litter, competition and the interaction litter x competition as fixed factors. F-values with their degrees of freedom for these effects are given. Blocks did not have significant effects. Yields in monocultures and mixtures were calculated per plant. Results of two-way ANOVA: $* * * P<0.001, * * P<0.01, * P<0.05$

ns non-significant

grass litter treatment the nitrogen uptake was strongly reduced (Fig. 2). In mixtures, the shrub plants were unable to absorb more nitrogen when grown with their own litter compared to the no litter treatment. In the grass litter treatment they barely absorbed any nitrogen. The combined nitrogen uptake of $C$. vulgaris and $D$. flexuosa was highest in the treatments with D. flexuosa litter $(P<0.05$, Fig. 2). The total nitrogen uptake in the two Calluna treatments was higher than in the no litter pots. In both mono and mixed cultures, $D$. flexuosa plants were able to absorb additional nitrogen released from $C$. vulgaris litter (Fig. 2).

Inorganic and dissolved organic nitrogen in the soil

In all the treatments the concentration of dissolved organic nitrogen is always more than $50 \%$ of the total dissolved soil nitrogen (Fig. 3). The production of inorganic nitrogen and dissolved organic nitrogen in the soil with $D$. flexuosa litter was significantly higher than in the treatments without litter or with $C$.

Table 4 Effects of litter treatment on the ratio between the shoot or root biomass of the two species (D. flexuosa:C.vulgaris) in mixtures (mean \pm se)

\begin{tabular}{lcr}
\hline Litter treatment & $\begin{array}{l}\text { Biomass ratio in mixture } \\
\text { shoot }\end{array}$ & $\begin{array}{l}\text { Biomass ratio in mixture } \\
\text { root }\end{array}$ \\
\hline No litter & $1.54 \pm 0.24^{\mathrm{a}}$ & $0.20 \pm 0.06^{\mathrm{a}}$ \\
C. vulgaris (high phenolics) & $5.14 \pm 1.61^{\mathrm{b}}$ & $2.43 \pm 1.30^{\mathrm{a}}$ \\
C. vulgaris (low phenolics) & $3.97 \pm 1.21^{\mathrm{ab}}$ & $0.86 \pm 0.58^{\mathrm{a}}$ \\
D. flexuosa & $17.93 \pm 2.98^{\mathrm{c}}$ & $10.96 \pm 4.01^{\mathrm{b}}$ \\
\hline
\end{tabular}

Different letters indicate significant differences between litter treatments (Tukey's test, $P<0.05$ ) 


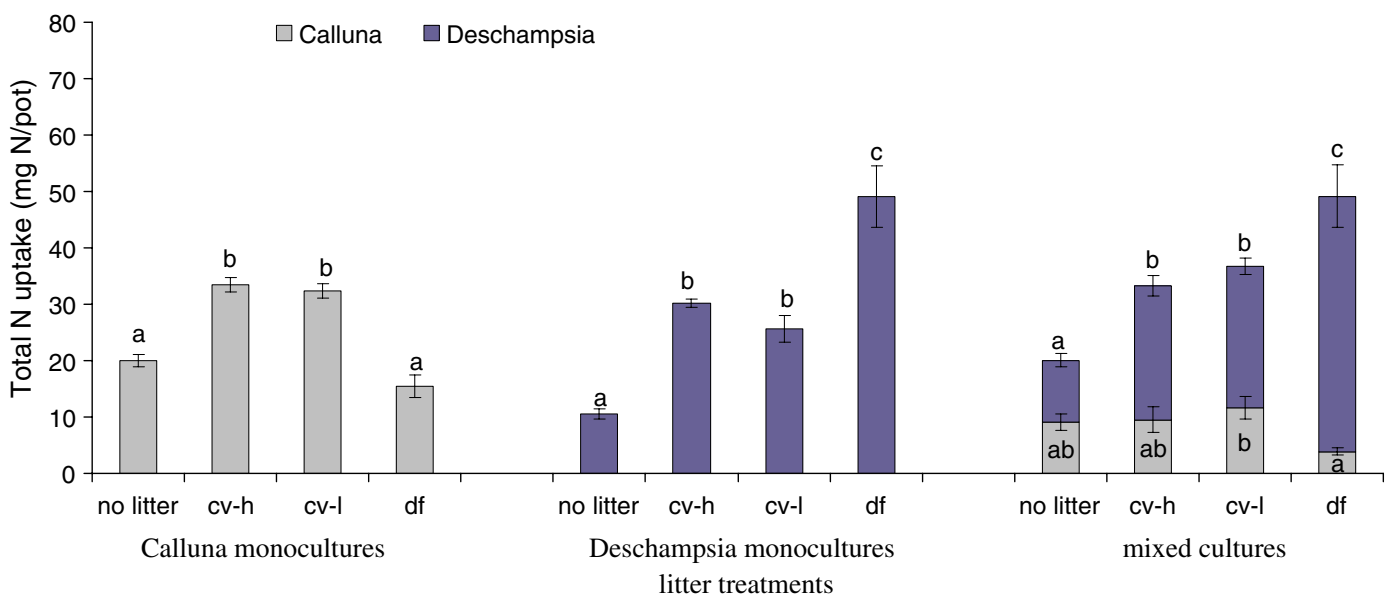

Fig. 2 Effects of litter treatments on the total amounts of absorbed nitrogen in the shoot and roots of C. vulgaris (light bars) and D. flexuosa (dark bars) per plant. Error bars show standard errors of the mean $(n=6)$. Different letters indicate

vulgaris litter $(P<0.05)$. After the first 2 months, $D$. flexuosa litter reduced the ratio DON: inorganic nitrogen, as can be seen from the significant interactions between time and litter (Table 5 and Fig. 3). In contrast, during the first two months $C$. vulgaris litter greatly increased this ratio. C. vulgaris litters with high and low concentrations of phenolics showed an immobilization of inorganic nitrogen during the first 8 weeks, as evidenced by the inorganic nitrogen being lower than in the control treatment (Fig. 3, $P<0.05$ ). significant differences between litter treatments (Tukey test, $P<$ 0.05). Litter treatments: no litter $=$ no litter applied, $\mathrm{cv}-\mathrm{h}=C$. vulgaris high phenolic concentration, $\mathrm{cv}-1=C$. vulgaris low phenolic concentration, $\mathrm{df}=D$. flexuosa

Only after 20 weeks did the $C$. vulgaris litters produce significantly more inorganic nitrogen and organic nitrogen than the control treatments $(P<0.05)$.

\section{Discussion}

Our results show that $C$. vulgaris plants compete with $D$. flexuosa more efficiently on nutrient-poor soils (no litter amendment or amended with litter relatively rich

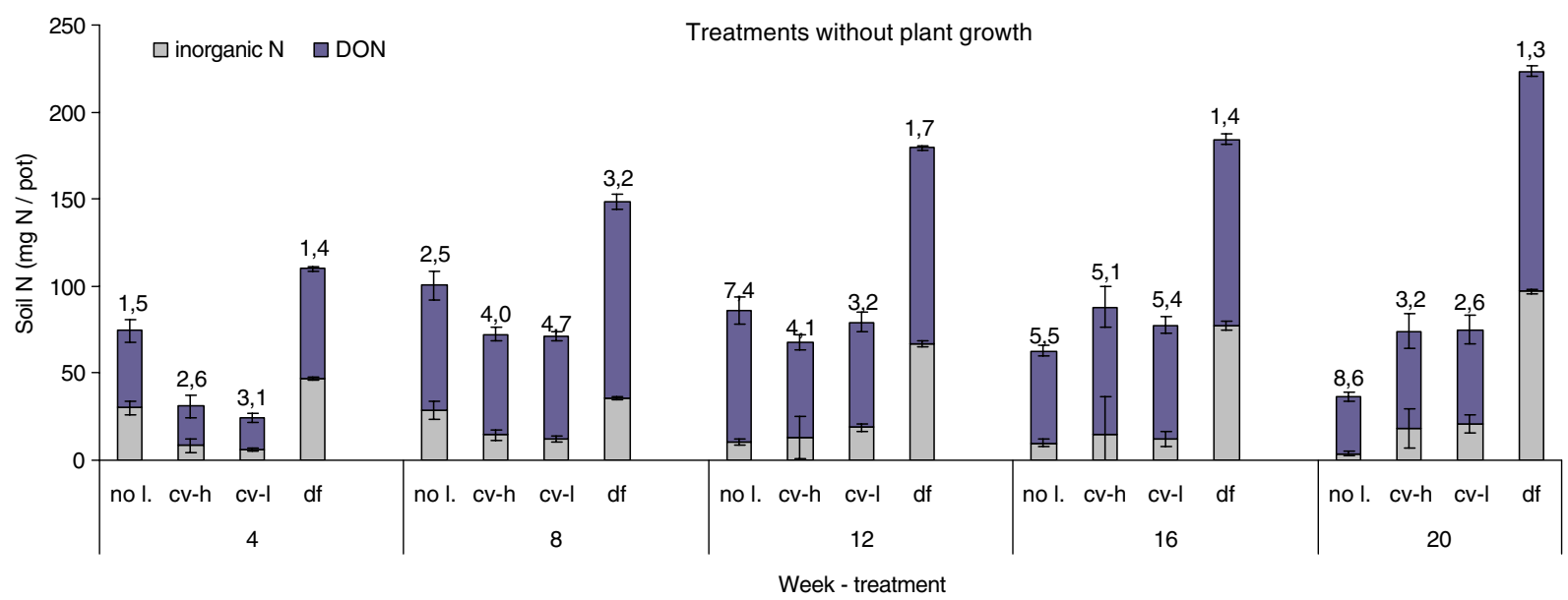

Fig. 3 Effect of litter treatments on the amounts of inorganic and dissolved organic nitrogen (DON) in treatments without plants during 20 weeks. Error bars show standard errors of the mean. At the top of each bar the ratio between DON and inorganic nitrogen is given. Litter treatments: no $1 .=$ no litter applied, $\mathrm{cv}-\mathrm{h}=C$. vulgaris high phenolic concentration, $\mathrm{cv}-\mathrm{l}=$ C. vulgaris low phenolic concentration, $\mathrm{df}=D$. flexuosa 
Table 5 Results of repeated measures two-way ANOVA of concentrations of inorganic $\mathrm{N}, \mathrm{DON}$, the ratio DON:inorganic nitrogen and $\mathrm{pH}\left(\mathrm{H}_{2} \mathrm{O}\right)$ in the control pots without plants

\begin{tabular}{|c|c|c|c|}
\hline Source & Measure & df & $F$ \\
\hline \multicolumn{4}{|c|}{ Between-subject effects: } \\
\hline \multirow[t]{4}{*}{ Litter } & Inorganic $\mathrm{N}$ & 3 & $44.101 * * *$ \\
\hline & DON & 3 & $72.704 * * *$ \\
\hline & DON: inorganic $\mathrm{N}$ & 3 & $7.738 * * *$ \\
\hline & $\mathrm{pH}\left(\mathrm{H}_{2} \mathrm{O}\right)$ & 3 & $0.542^{\mathrm{ns}}$ \\
\hline \multicolumn{4}{|c|}{ Within-subject contrasts: } \\
\hline \multirow[t]{4}{*}{ Time } & Inorganic $\mathrm{N}$ & 4 & $3.592 *$ \\
\hline & DON & 4 & $43.818 * * *$ \\
\hline & DON: inorganic $\mathrm{N}$ & 4 & $15.601 * * *$ \\
\hline & $\mathrm{pH}\left(\mathrm{H}_{2} \mathrm{O}\right)$ & 3 & $181.560 * * *$ \\
\hline \multirow[t]{4}{*}{ Time $\times$ Litter } & Inorganic $\mathrm{N}$ & 12 & $5.355 * * *$ \\
\hline & DON & 12 & $2.811 * *$ \\
\hline & DON: inorganic $\mathrm{N}$ & 12 & $3.970 * * *$ \\
\hline & $\mathrm{pH}\left(\mathrm{H}_{2} \mathrm{O}\right)$ & 9 & $2.219 *$ \\
\hline
\end{tabular}

$F$-values and their degrees of freedom are given for effects of litter treatment, time and interaction time*litter

$* * * P<0.001, * * P<0.01, * P<0.05$

$n s$ non-significant

in phenolics) than on soils with grass litter. Only in treatments without competing grasses could C. vulgaris benefit from the nutrients in its own litter. It was striking that Calluna growth was strongly suppressed in treatments with grass litter, while D. flexuosa produced most biomass when growing on its own litter. Moreover, D. flexuosa was able to outcompete C. vulgaris both on shrub and grass litter. C. vulgaris was significantly less able to absorb nitrogen in the grass litter treatments than in the other treatments. In contrast, $C$. vulgaris growing in monocultures was able to use all the available nitrogen produced in the treatments with heather litter. The ratio between the biomass of the two species in mixtures shows that the difference in biomass production between the two plant species was largest on the grass litter and was much smaller in the treatment without litter.

Shrub plants were inhibited by the presence of grass plants and showed the highest production in the monocultures. The plants were not affected by the different concentrations of phenolics in the two shrub litter types they were growing on. Northup et al. (1995, 1998) argued that plant species with high concentrations of secondary plant metabolites could absorb larger fractions of the organic nitrogen pool than species with lower concentrations, allowing such species to outcompete species less able to absorb organic nitrogen. If this were so, $C$. vulgaris plants should have been able to outgrow D. flexuosa plants on their own Calluna litter, which is rich in phenolics. Our replacement diagrams show, however, that $C$. vulgaris plants were not able to produce more biomass than $D$. flexuosa plants in any of the treatments. Only in monocultures $C$. vulgaris did benefit from its own litter. It seems that the hypothesized monopoly of $C$. vulgaris on the organic nitrogen pool does not increase the competitiveness of C. vulgaris.

One explanation of the above behaviour could be that $D$. flexuosa is also able to exploit complex sources of organic nitrogen. In this experiment we found that grass plants were able to use litter sources with high concentrations of phenolics equally well as the shrub plants. Previous competition studies between heather and grass and between $C$. vulgaris and D. flexuosa specifically, only considered competition for inorganic nitrogen sources (Berendse and Aerts 1984; Mickel et al. 1991; Berendse 1994; Alonso et al. 2001; Britton et al. 2003). The study by Näsholm et al. (1998) with dual-labelled glycine in a boreal forest provided the first evidence for significant organic nitrogen uptake by D. flexuosa, as $64 \%$ of the added glycine was taken up as intact glycine. It was shown that $D$. flexuosa absorbed the same amount (about 30\%) of the dual-labelled glycine as the ericaceous shrub Vaccinium myrtillus.

As shown by the replacement diagrams of the shoot biomass (Fig. 1), D. flexuosa was not inhibited by the presence of $C$. vulgaris plants. We had expected that the high concentration of phenolics in C. vulgaris litter would lead to reduced nitrogen mineralization (Kraus et al. 2003; Bowman et al. 2004), subsequently inhibiting the growth of grass plants on shrub litters compared with the treatments without litter amendment. However, we found no such growth inhibition of the grass plants in the shrub litter treatments although they produced less biomass compared to grass plants in the grass litter treatments. The two Calluna litter types with different concentrations of phenolics did not affect the growth or the competitive ability of the grass plants.

Other competition studies have shown that grasses are able to benefit more than shrub plants from an 
increased soil nitrogen supply (Mickel et al. 1991; Hartley and Amos 1999; Britton et al. 2003). Our results confirm this, as D. flexuosa absorbed most nitrogen and produced most biomass on its own litter, which had the highest nitrogen concentration.

We did not find any difference in plant growth on the two different $C$. vulgaris litter types, even though these varied significantly in the concentration of total phenolics. This lack of difference can be due to the low concentrations of condensed tannins in $C$. vulgaris litter, which did not differ between the two litter types. Condensed tannins in litter can inhibit mineralization rates significantly due to their higher protein-binding capacity compared to the hydrolysable tannins (Schimel et al. 1996, 1998; Bradley et al. 2000; Fierer et al. 2001; Kraus et al. 2003). Bradley et al. (2000) reported that adding condensed tannins from Kalmia and balsam fir foliage reduced mineral nitrogen availability in black spruce humus. In addition, Schimel et al. (1996, 1998) found that high molecular weight fractions of poplar tannins bound nitrogen-containing substrates and reduced mineral nitrogen pools, whereas the low molecular weight fractions acted as substrates or toxins leading to increased immobilization by the increased microbial growth. In our experiment we also found immobilization of inorganic nitrogen in the shrub litter treatments. The pots with $C$. vulgaris litter produced lower concentrations of soil nitrogen compared to the control pots and the pots with grass litter during the first 8 weeks (Fig. 3).

Arbuscular mycorrhizal fungi have not been found to degrade protein-phenolic complexes (Hodge et al. 2001). But molecular analysis based on the nuclear ribosomal internal transcribed spacer (ITS) region revealed that some roots of D. flexuosa plants are colonized by beneficial fungal endophytes belonging to the Helotiales (Zijlstra et al. 2005). The majority $(68 \%)$ of the ericaceous root isolates analysed were found to belong to the Helotiales. Apparently, some grass root endophytes seem to be related to ericaceous root isolates forming ericoid mycorrhizae, e.g. Hymenoscyphus ericae complexes of fungal strains (Zijlstra et al. 2005). Such strains are able to degrade soluble phenolics (Bending and Read 1997; Zijlstra et al. 2005) and enhanced significantly nitrogen uptake in inoculated $D$. flexuosa and $C$. vulgaris seedlings compared to the inoculated control plants (Zijlstra et al. 2005).
Growth and nitrogen uptake in Calluna vulgaris was significantly inhibited in the grass litter treatments compared to the treatment without litter. At the start of the experiment, $C$. vulgaris plants established more slowly in this litter treatment-perhaps due to toxic effects of the grass litter on shrub roots. Sánchez-Moreiras et al. (2003) reported on allelopathic effects of grasses due to the presence of substances such as phenolic acids, hydroxamic acid, alkaloids and quinones. More than 40 years ago, Jarvis (1964) showed that D. flexuosa humus produces allelopathic effects on plant growth. In Jarvis's experiment with $D$. flexuosa and $C$. vulgaris litter, $D$. flexuosa litter inhibited the growth of oak roots drastically (to almost no root growth), whereas in contrast the oak roots developed well on C. vulgaris litter, achieving $90 \%$ of the growth of the control treatments. Furthermore, not only did the grass litter produce toxic effects on seedlings, the root exudates of $D$. flexuosa were also found to inhibit seedling growth (Jarvis 1964). Before the start of our experiment we measured the concentration of total phenolics in $D$. flexuosa litter and found it was very low compared to the concentrations found in C. vulgaris litter. It therefore seems unlikely that the phenolics in grass litter would be responsible for toxic effects. We cannot exclude the possibility that components other than phenolics could have been playing an inhibitory role. Clearly, the results of our experiment require further investigation to elucidate the possible allelopathic effects in litter of $D$. flexuosa as not only plant growth may be affected, but also mycorrhizal fungi present in the ericaceous roots could have been inhibited by the release of toxic substances or the activity of other litter-feeding organisms (Jarvis 1964; Rose et al. 1983).

Our results emphasize again that $C$. vulgaris plants are much less able to outcompete $D$. flexuosa under nutrient-rich conditions than under less fertile circumstances. Consequently, they confirm that increased atmospheric nitrogen deposition can weaken the competitive ability of $C$. vulgaris plants in heathland ecosystems. Concentrations of phenolics in ericaceous litter that are reduced due to increased atmospheric deposition of nitrogen do not have any effect on the competition between grass and heather. We conclude that the notion that $C$. vulgaris plants can dominate the organic nitrogen pool because they produce leaves rich in phenolics and have an exclusive symbiosis 
with ericoid mycorrhizal fungi has to be revised. $D$. flexuosa seems to have adjusted to the nutrient-poor system too and is well able to use litter rich in phenolics. In addition, the fungal endophytes thought to be specific to ericaceous plants have turned out to be not that specific (Zijlstra et al. 2005). The expansion of grass species after an increased input of nitrogen can still be most properly explained by their ability to respond more rapidly than ericaceous dwarf shrubs to increased nutrient supply (Berendse and Elberse 1990).

Acknowledgements We thank Jan van Walsem, Frans Möller and Henk van Roekel for their assistance in the greenhouse and the laboratory. De Hoge Veluwe National Park is acknowledged for permission to collect $C$. vulgaris seedlings. Moreover, we thank two anonymous referees for their many valuable comments.

Open Access This article is distributed under the terms of the Creative Commons Attribution Noncommercial License which permits any noncommercial use, distribution, and reproduction in any medium, provided the original author(s) and source are credited.

\section{References}

Aerts R, Berendse F (1988) The effects of increased nutrient availability on vegetation dynamics in wet heathlands. Vegetatio 63:63-69

Aerts R, Berendse F, de Caluwe H, Schmitz M (1990) Competition in heathland along an experimental gradient of nutrient availability. Oikos 57:320-318

Alonso I, Hartley SE, Thurlow M (2001) Competition between heather and grasses on Scottish moorlands: Interacting effects of nutrient enrichment and grazing regime. J Veg Sci 12:249-260

Barker CG, Power SA, Bell JNB, Orme CDL (2004) Effects of habitat management on heathland response to atmospheric nitrogen deposition. Biol Cons 120:41-52

Bending GD, Read DJ (1997) Lignin and soluble phenolic degradation by ectomycorrhizal and ericoid mycorrhizal fungi. Mycol Res 101:1348-1354

Berendse F (1994) Competition between plant populations at low and high nutrient supplies. Oikos 71:253-260

Berendse F, Aerts R (1984) Competition between Erica tetralix L. and Molinia cearulea (L.) Moench as affected by the availability of nutrients. Oecologia Plantarum 5:3-14

Berendse F, Elberse WTh (1990) Competition and nutrient availability in heathland and grassland ecosystems. In: Grace J, Tilman D (eds) Perspectives on plant competition. Academic Press, Florida, Orlando, pp 93-116

Berendse F, Oudhof H, Bol J (1987) A comparative study on nutrient cycling in wet heathland ecosystems. I: Litter production and nutrient losses from the plant. Oecologia (Berl.) 74:174-184
Bowman WD, Steltzer H, Rosenstiel TN, Cleveland CC, Meier CL (2004) Litter effects of two co-occurring alpine species on plant growth, microbial activity and immobilization of nitrogen. Oikos 104:336-344

Bradley RL, Titus BD, Preston CM (2000) Changes to mineral $\mathrm{N}$ cycling and microbial communities in black spruce humus after additions of (NH4) 2SO4 and condensed tannins extracted from Kalmia angustifolia and balsam fir. Soil Biol Biochem 32:1227-1240

Britton A, Marrs R, Pakeman R, Carey P (2003) The influence of soil-type, drought and nitrogen addition on interactions between Calluna vulgaris and Deschampsia flexuosa: implications for heathland regeneration. Plant Ecol 166:93-105

Falkengren-Grerup U, Mansson KF, Olsson MO (2000) Uptake capacity of amino acids by ten grasses and forbs in relation to soil acidity and nitrogen availability. Environ Exper Bot 44:207-219

Fierer N, Schimel JP, Cates RG, Zou Z (2001) The influence of balsam poplar tannins fractions on carbon and nitrogen dynamics in Alaskan taiga floodplain soils. Soil Biol Biochem 33:1827-1839

Hartley SE, Amos L (1999) Competitive interactions between Nardus stricta L. and Calluna vulgaris (L.) Hull: the effect of fertilizer and defoliation on above- and below-ground performance. J Ecol 87:330-340

Heil GW, Bruggink M (1987) Competition for nutrients between Calluna vulgaris and Molinia caerulea. Oecol 73:105-107

Hodge A (2001) Arbuscular mycorrhizal fungi influence decomposition of, but not plant nutrient capture from, glycine patches in soil. New Phytol 151:725-734

Hodge A, Campbell CD, Fitter AH (2001) An arbuscular mycorrhizal fungus accelerates decomposition and acquires nitrogen directly from organic material. Nature 413:297-299

Inderjit S, Mallik AU (1999) Nutrient status of black spruce (Picea mariana [Mill.] BSP) forest soils dominated by Kalmia angustifolia L. Acta Oecol 20:87-92

Jarvis PG (1964) Interference by Deschampsia flexuosa (L.) Trin. Oikos 15:56-78

Kraus TEC, Dahlgren RA, Zasoski RJ (2003) Tannins in nutrient dynamics of forest ecosystems - a review. Pl Soil 256:41-66

Mickel S, Brunschön S, Fangmeier A (1991) Effects of nitrogen nutrition on growth and competition of Calluna vulgaris (L.) Hull and Deschampsia flexuosa (L.) Trin. Angew Botanik 65:359-372

Näsholm T, Ekblad A, Nordin A, Giesler R, Högberg M, Högberg P (1998) Boreal forest plants take up organic nitrogen. Nature 392:914-916

Northup RR, Yu Z, Dahlgren RA, Vogt KA (1995) Polyphenol control of nitrogen release from pine litter. Nature 377:227-229

Northup RR, Dahlgren RA, McColl JG (1998) Polyphenols as regulators of plant-litter-soil interactions in northern California's pygmy forest: a positive feedback? Biogeochem 42:189-220

Porter LJ, Hrstich LN, Chan BC (1986) The conversion of procyanidins and prodelphinidins to cyanidins and delphinidin. Phytochem 25:223-230 
Rose SL, Perry DA, Pilz D, Schoeneberger MM (1983) Allelopathic effects of litter on the growth and colonization of mycorrhizal fungi. J Chem Ecol 9:1153-1162

Sánchez-Moreiras AM, Weiss OA, Reigosa-Roger MJ (2003) Allelopathic evidence in the Poaceae. Bot Review 69:300-319

Schimel JP, Van Cleve K, Cates RG, Clausen TP, Reichardt PB (1996) Effects of balsam poplar (Populus balsamifera) tannins and low molecular weight phenolics on microbial activity in taiga floodplain: soil implications for changes in $\mathrm{N}$ cycling during succession. Can J Bot 74:84-90

Schimel JP, Cates RG, Ruess R (1998) The role of balsam poplar secondary chemicals in controlling soil nutrient dynamics through succession in the Alaskan taiga. Biogeochem 42:221-234

Smith SE, Read DJ (1997) Mycorrhizal symbiosis, 2nd edn. Academic, London

Sokolovski SG, Meharg AA, Maathuis JM (2001) Calluna vulgaris root cells show increased capacity for amino acid uptake when colonized with the mycorrhizal fungus Hymenoscyphus ericae. New Phyt 155:525-530

Waterman PG, Mole S (1994) Analysis of phenolic plant metabolites. Blackwell Scientific Publications, Methods in Ecology Series. Oxford

Yu Z, Northup RR, Dahlgren RA (1993) Determination of dissolved organic nitrogen using persulfate oxidation and conductimetric quantification of nitrate-nitrogen. Comm Soil Sci Plant Anal 25:3161-3169

Zijlstra JD, Berendse F (2009) The effect of nutrient supply and light intensity on tannins and mycorrhizal colonisation in Dutch heathland ecosystems. Plant Ecology 201:661-675. doi:10.1007/s11258-008-9554-3

Zijlstra JD, Van 't Hof P, Baar J, Verkley GJM, Summerbell RC, Paradi I, Braakhekke WG, Berendse F (2005) Diversity of symbiotic root endophytes of the Helotiales in ericaceous plants and the grass, Deschampsia flexuosa. Stud Mycol 53:147-162 